\title{
Treatment of severe respiratory insufficiency in diffuse chronic lung disease by tracheostomy and intermittent positive pressure ventilation (IPPV)
}

\author{
H. Sund Kristensen Ove Jessen Knud Rasmussen \\ Departments of Epidemiology, Otology and Clinical Chemistry, Blegdamshospitalet, Copenhagen
}

RESPIRATORY failure resulting from diffuse chronic lung disease has been treated by artificial ventilation for 15 years (Boutourline-Young \& Whittenberger, 1951; Mollaret et al., 1958; Munck, Sund Kristensen \& Lassen, 1961; Lassen, 1962; Lissac \& Pocidalo, 1963; Sluiter, Blokzijl \& van Dijl, 1963; Herzog \& Engelhart, 1964; Bradley, Spencer \& Semple, 1964; Bates et al., 1965; Bydlowski et al., 1965; Castaing et al., 1965; Grendahl \& Refsum, 1965; Sadoul, Aug \& Gay, 1965). This active form of therapy has gained acceptance in centres equipped with technical and staffing facilities adequate for its successful application, but other forms of therapy and prophylaxis are employed in less well equipped centres, particularly as individual physicians hold widely divergent opinions on the merits of artificial ventilation and the indications for its use. This controversy cannot as yet be resolved on the basis of general principles.

After 1955 (Bjørneboe et al.) the treatment of this disease at the Blegdamshospitalet has been centralized in the Department of Epidemiology where IPPV had been extensively used during the poliomyelitis epidemics in 1952-53 (Lassen, 1956); the principles of prolonged artificial ventilation evolved during that period were applied.

\section{Clinical material}

Patients were placed in three broad clinical categories because the functional capacity of these subjects prior to the acute exacerbation provided the only significant prognostic criterion as was pointed out previously (Munck et al., 1961). Tables 1 and 2 show that only two out of fifty-six patients with fair respiratory reserve died whereas fifteen of the eighty more severely disabled patients could not be saved.

Group A. Patients able to undertake full or parttime work before the exacerbation that led to respiratory failure.

Group B. Patients unable to work, but able to look after personal requirements such as the household shopping.

Group C. Patients so severely incapacitated as to be
TABLE 1

Distribution according to age at the time of tracheostomy and respiratory reserve prior to acute exacerbation

\begin{tabular}{|c|c|c|c|c|}
\hline Age & $\underset{\text { A }}{\text { Group }}$ & $\underset{\text { B }}{\text { Group }}$ & $\underset{\mathrm{C}}{\text { Group }}$ & Total \\
\hline $\begin{array}{l}\text { Less than } 50 \text { years } \\
50-60 \text { years } \\
60-70 \text { years } \\
\text { More than } 70 \text { years }\end{array}$ & $\begin{aligned} & 7(1) \\
& 22(1) \\
& 25(0) \\
& 2(0)\end{aligned}$ & $\begin{aligned} 7 & (0) \\
21 & (2) \\
19 & (5) \\
12 & (4)\end{aligned}$ & $\begin{array}{l}5(1) \\
6(0) \\
7(3) \\
3(0)\end{array}$ & $\begin{array}{l}19(2) \\
49(3) \\
51(8) \\
17(4)\end{array}$ \\
\hline Total & $56(2)$ & $59(11)$ & $21(4)$ & $136(17)$ \\
\hline
\end{tabular}

Deaths during respirator treatment are indicated in parentheses. For definition of groups, see text.

TABLE 2

Survival rates for patients treated by tracheostomy and $\overrightarrow{\hat{O}}$ artificial ventilation for respiratory insufficiency in chronic $\overline{3}$ diffuse lung disease

\begin{tabular}{|c|c|c|c|c|}
\hline \multirow{2}{*}{ Time } & \multirow{2}{*}{$\begin{array}{l}\text { Total } \\
(\%)\end{array}$} & \multicolumn{3}{|c|}{$\begin{array}{c}\text { Respiratory reserve before acute } \\
\text { exacerbation }\end{array}$} \\
\hline & & $\begin{array}{l}\text { Group } \\
\text { A }(\%)\end{array}$ & $\begin{array}{l}\text { Group } \\
\text { B (\%) }\end{array}$ & $\begin{array}{l}\text { Group } \\
\text { C (\%) }\end{array}$ \\
\hline Respirator & $88(136)$ & $96(56)$ & $81(59)$ & $81(21)$ \\
\hline Discharge & $75(136)$ & $86(56)$ & $71(59)$ & $57(21)$ \\
\hline 3 months & $65(136)$ & $73(56)$ & $66(59)$ & $38(21)$ \\
\hline 6 months & $54(136)$ & $70(56)$ & $53(59)$ & 19(21) \\
\hline 9 months & $51(134)$ & 69(55) & 44(59) & $20(20)$ \\
\hline 1 year & 44(130) & $64(55)$ & $35(55)$ & $15(20)$ \\
\hline 2 years & $36(101)$ & 49(45) & $32(41)$ & $7(15)$ \\
\hline 3 years & 39 (85) & $58(36)$ & $32(37)$ & $0(12)$ \\
\hline 4 years & $35(62)$ & $55(29)$ & $26(23)$ & $0(10)$ \\
\hline 5 years & 24 (41) & $44(18)$ & $15(13)$ & $0(10)$ \\
\hline 6 years & $15(26)$ & 23(13) & 14 (7) & $0(6)$ \\
\hline 7 years & 14 (14) & $40(5)$ & 0 (6) & 0 (3) \\
\hline 8 years & 11 (9) & 33 (3) & 0 (4) & 0 (2) \\
\hline 9 years & $\begin{array}{ll}0 & \text { (2) }\end{array}$ & $0(0)$ & 0 (2) & $0(0)$ \\
\hline
\end{tabular}

The figures in parentheses indicate the number of patients observed in the group concerned.

unable to leave their beds or their rooms. A few of $\stackrel{\overrightarrow{\mathbb{D}}}{\stackrel{Q}{\varrho}}$ these had permanent tracheostomies and a few more used oxygen therapy at home. 
TABLE 3

A. Oxygen saturation, $\mathrm{CO}_{2}$-tension and $\mathrm{pH}$ of arterial blood before, during and after artificial ventilation

\begin{tabular}{|c|c|c|c|c|}
\hline & Group & $\begin{array}{c}\text { Oxygen } \\
\text { saturation (\%) }\end{array}$ & $\begin{array}{c}\mathrm{CO}_{2} \text { tension } \\
(\mathrm{mmHg})\end{array}$ & pH \\
\hline $\begin{array}{l}\text { Shortly before tracheostomy, } \\
\text { spontaneous respiration, plus } \\
\text { oxygen }\end{array}$ & $\begin{array}{l}\mathbf{A} \\
\mathbf{B} \\
\mathbf{C}\end{array}$ & $\begin{array}{l}65 \cdot 7 \pm 3 \cdot 0(35) \\
68 \cdot 2 \pm 2 \cdot 8(42) \\
66 \cdot 0 \pm 4 \cdot 6(17)\end{array}$ & $\begin{array}{l}82 \cdot 5 \pm 3 \cdot 9(36) \\
87 \cdot 1 \pm 3 \cdot 7(43) \\
77 \cdot 2 \pm 4 \cdot 7(17)\end{array}$ & $\begin{array}{l}7 \cdot 259 \pm 0 \cdot 017(36) \\
7 \cdot 253 \pm 0 \cdot 021(42) \\
7 \cdot 299 \pm 0 \cdot 026(17)\end{array}$ \\
\hline During respirator treatment & $\begin{array}{l}\mathbf{A} \\
\mathbf{B} \\
\mathbf{C}\end{array}$ & $\begin{array}{l}92 \cdot 1 \pm 0 \cdot 7(53) \\
92 \cdot 9 \pm 1 \cdot 0(56) \\
93 \cdot 9 \pm 0 \cdot 8(18)\end{array}$ & $\begin{array}{l}51 \cdot 3 \pm 1 \cdot 4(53) \\
48 \cdot 6 \pm 1 \cdot 1(57) \\
47 \cdot 6 \pm 3 \cdot 4(18)\end{array}$ & $\begin{array}{l}7 \cdot 441 \pm 0 \cdot 010(53) \\
7 \cdot 438 \pm 0 \cdot 010(57) \\
7 \cdot 450 \pm 0 \cdot 018(18)\end{array}$ \\
\hline $\begin{array}{l}\text { After treatment, spontaneous } \\
\text { respiration, no oxygen }\end{array}$ & $\begin{array}{l}\mathbf{A} \\
\mathbf{B} \\
\mathbf{C}\end{array}$ & $\begin{array}{l}85 \cdot 3 \pm 1 \cdot 1(43) \\
85 \cdot 4 \pm 1 \cdot 1(35) \\
84 \cdot 0 \pm 3 \cdot 0(10)\end{array}$ & $\begin{array}{l}47 \cdot 9 \pm 1 \cdot 2(43) \\
50 \cdot 2 \pm 1 \cdot 6(35) \\
47 \cdot 0 \pm 2 \cdot 7(10)\end{array}$ & $\begin{array}{l}7 \cdot 408 \pm 0 \cdot 008(43) \\
7 \cdot 412 \pm 0 \cdot 008(35) \\
7 \cdot 428 \pm 0 \cdot 020(10)\end{array}$ \\
\hline
\end{tabular}

B. Oxygen saturation, $\mathrm{CO}_{2}$-tension and $\mathrm{pH}$ of arterial blood before tracheostomy (spontaneous respiration plus oxygen) in: (a) patients who die during admission or within 6 months after discharge, and (b) patients alive 6 months after discharge

\begin{tabular}{llll}
\hline & $\begin{array}{c}\text { Oxygen } \\
\text { saturation }(\%)\end{array}$ & $\begin{array}{c}\mathrm{CO}_{2} \text {-tension } \\
(\mathrm{mmHg})\end{array}$ & pH \\
\hline $\begin{array}{l}\text { Death during admission or within } \\
\quad \text { months }\end{array}$ & $64 \cdot 4 \pm 2 \cdot 5(45)$ & $79 \cdot 4 \pm 3 \cdot 2(46)$ & $7 \cdot 275 \pm 0 \cdot 018(45)$ \\
6 months survival & $69 \cdot 1 \pm 2 \cdot 7(49)$ & $87 \cdot 6 \pm 3 \cdot 5(50)$ & $7 \cdot 254 \pm 0 \cdot 016(50)$ \\
\hline
\end{tabular}

The figures are mean values. The standard error of the mean is given. The figures in parentheses are the number of observations.

TABLE 4

Mental state of the patients before tracheostomy

\begin{tabular}{|c|c|c|c|c|c|c|}
\hline & $\underset{\mathbf{A}}{\text { Group }}$ & $\begin{array}{c}\text { Group } \\
\text { B }\end{array}$ & $\underset{\text { Croup }}{\text { Group }}$ & Total & $\begin{array}{l}\text { Deaths } \\
\text { during } \\
\text { IPPV }\end{array}$ & $\begin{array}{c}\text { Total } \\
\text { s deaths } 6 \\
\text { months } \\
\text { after } \\
\text { discharge }\end{array}$ \\
\hline $\begin{array}{l}\text { Conscious } \\
\text { Somnolent, }\end{array}$ & 3 & 6 & 1 & 10 & 0 & 4 \\
\hline $\begin{array}{l}\text { quiet } \\
\text { Somnolent, }\end{array}$ & 20 & 28 & 11 & 59 & 9 & 31 \\
\hline agitated & 6 & 4 & 1 & 11 & 2 & 4 \\
\hline $\begin{array}{l}\text { Comatose } \\
\text { Not }\end{array}$ & 19 & 17 & 8 & 44 & 5 & 20 \\
\hline recorded & 8 & 4 & 0 & 12 & 1 & 3 \\
\hline
\end{tabular}

TABLE 5

Presence of oedema, cor pulmonale and obesity correlated to death or survival of the patients

\begin{tabular}{lrrrr}
\hline & $\begin{array}{c}\text { Deaths } \\
\text { during } \\
\text { IPPV }\end{array}$ & $\begin{array}{c}\text { Other } \\
\text { deaths } \\
\text { within 6 6 } \\
\text { months }\end{array}$ & $\begin{array}{c}\text { Patients } \\
\text { surviv- } \\
\text { ing 6 } \\
\text { months }\end{array}$ & Total \\
\hline Odema $\leqslant 3$ months & 2 & 10 & 14 & 26 \\
Oedema 3-12 months & 1 & 6 & 5 & 12 \\
Oedema $\geqslant 12$ months & 5 & 7 & 11 & 23 \\
Cor pulmonale & 6 & 21 & 31 & 58 \\
Obesity & 3 & 6 & 10 & 19 \\
Total No. of patients & 17 & 45 & 74 & 136 \\
\hline
\end{tabular}

The clinical condition during the acute exacerbation, the results of arterial blood gas analysis (Table 3 ), the mental state of the patients (Table 4) and the presence of cor pulmonale or oedema (Table 5) did not form reliable guides to prognosis and the length of the previous history of the disease did not correlate with the mortality. In fact Table 6 shows

TABLE 6

Duration of lung symptoms correlated to death or survival of the patients

\begin{tabular}{lcccc}
\hline & $\begin{array}{c}\text { Deaths } \\
\text { during } \\
\text { IPPV }\end{array}$ & $\begin{array}{c}\text { Other } \\
\text { deaths } \\
\text { within 6 } 6 \\
\text { months }\end{array}$ & $\begin{array}{c}\text { Patients } \\
\text { surviv- } \\
\text { ing 6 } \\
\text { months }\end{array}$ & Total \\
\hline $\begin{array}{l}\text { Lung symptoms }<10 \\
\text { years }\end{array}$ & 7 & 12 & 20 & 39 \\
$\begin{array}{l}\text { Lung symptoms 11-20 } \\
\text { years }\end{array}$ & 4 & 16 & 20 & 40 \\
$\begin{array}{l}\text { Lung symptoms }>20 \\
\begin{array}{c}\text { years } \\
\text { Not recorded }\end{array}\end{array}$ & 6 & 12 & 33 & 51 \\
$\begin{array}{l}\text { Total } \\
\text { motal }\end{array}$ & 17 & 45 & 74 & 136 \\
\hline
\end{tabular}

that many patients with symptoms for less than 10 years progressed rapidly to a fatal outcome. These findings are similar to those of Sluiter et al. (1963).

All 111 patients treated had chronic bronchitis, usually for more than 10 years (Table 6) with varying degrees of pulmonary emphysema and fibrosis. Most of the patients were 50-70 years of age 
(Table 1) and there were five times as many men as women. Fifty-eight patients had electrocardiographic evidence of cor pulmonale and more than half were in heart failure when treatment was commenced (Table 5).

The commonest cause of the acute exacerbation (Table 7) was infection; other causes were lung

TABLE 7

Causes of deterioration necessitating tracheostomy

\begin{tabular}{|c|c|c|c|c|c|c|}
\hline & $\underset{\text { A }}{\text { Group }}$ & $\underset{\text { B }}{\text { Group }}$ & $\underset{\mathrm{C}}{\text { Group }}$ & Total & $\begin{array}{l}\text { Deaths } \\
\text { during } \\
\text { IPPV }\end{array}$ & $\begin{array}{c}\text { Total } \\
\text { deaths } 6 \\
\text { months } \\
\text { after } \\
\text { discharge }\end{array}$ \\
\hline Total & 56 & 59 & 21 & 136 & 17 & 62 \\
\hline \multicolumn{7}{|c|}{$\begin{array}{l}\text { Acute bronchitis; } \\
\text { acute }\end{array}$} \\
\hline pneumoni & ia 38 & 35 & 10 & 83 & 12 & 37 \\
\hline Asthma & 2 & 2 & 0 & 4 & 1 & 1 \\
\hline Morphine & 8 & 2 & 1 & 11 & 0 & 2 \\
\hline Oxygen & 8 & 7 & 4 & 19 & 2 & 11 \\
\hline Other causes & 7 & 16 & 9 & 32 & 3 & 17 \\
\hline
\end{tabular}

infarcts, bleeding gastroduodenal ulcer, alcohol intoxication, pneumothorax, diabetic precoma, hepatic coma, barbiturate intoxication, pancreatitis, tachycardia and heart failure. In several cases, the cause of the acute exacerbation could not be determined. In a number, incorrect diagnosis such as lung oedema for which opiates were administered, excessive oxygen therapy due to inexact flowmeters and insufficient supervision and other similar avoidable factors contributed to deterioration. Finally, a number of patients who are not considered further in this report were treated by oral intubation for 24-48 hr, aspiration of endobronchial secretions and intermittent positive pressure ventilation, and these patients avoided tracheostomy. In most of the patients who required tracheostomy well-supervised conservative treatment had failed to prevent deterioration.

\section{Clinical condition before tracheostomy}

The clinical condition during the acute episodes was so grave, that survival was considered improbable without artificial ventilation. In ten cases the mental state of the patients was relatively unaffected but one-third of the cases were in coma, and the remaining patients were somnolent (Table 4). Their arterial blood gases (breathing oxygen-enriched mixtures via a nasopharyngeal catheter) are presented in Table 3 . The mean values were very similar in groups $\mathbf{A}, \mathbf{B}$ and $\mathbf{C}$ with oxygen saturations between $66 \%$ and $68 \%, \mathrm{PaCO}_{2}$ about $80 \mathrm{mmHg}$, and pH between $7 \cdot 25$ and $7 \cdot 30$. We see from this that mental changes and arterial blood gas alterations formed the major indications for treatment by artificial ventilation.

\section{Treatment by tracheostomy and IPPV}

Tracheostomy was usually performed by an ear, nose and throat surgeon with the aid of cyclopropane or halothane anaesthesia administered by an anaesthetist. All patients were intubated with an orotracheal tube and ventilation was controlled $\vec{P}$ with the aid of a muscle relaxant during the opera $\vec{z}$ tion of tracheostomy. A transverse skin incision was preferred and the thyroid gland was divided necessary. Fenestration of the anterior wall of the trachea was made at the level of the second or thirds tracheal ring and a large size Rüsch tube was used. Arterial hypotension occurred at this stage in $0_{0}^{\circ}$ a number of patients and most often responded tơ treatment by volume-expanders (Dextran) and $+\overrightarrow{+}$ occasionally, vasopressors.

A stomach tube was passed initially in most casesas abdominal distension was not infrequent, and fluid could usually be aspirated from the stomach․ This abdominal distension disappeared 12-48 hto after tracheostomy: the patients regained conscious $\$$ ness and were allowed to drink and eat. A Lundiai respirator which is volume-cycled and functions at $\mathbb{D}$ preset rate was used to ventilate the lungs with $40-60 \%$ oxygen and a minute volume of 5-6 litres? After some hours, ventilatory volumes were in creased and oxygen concentration reduced. Bloof pressure, pulse rate and respiratory minute volumes were monitored hourly and the efficiency of ven 3 tilation was estimated by measuring arterial $\mathrm{pH}^{\text {f }}$ standard bicarbonate, $\mathrm{PCO}_{2}$ and oxygen saturation:The patients were shifted from the supine position several times a day and lung physiotherapy was carried out twice a day. Drainage of the tracheo 3 bronchial tree in head-down or prone positions was. not used as the patients responded badly to these positions. Tracheal secretions were aspirated with sterile catheters when necessary and the appropriate antibiotics were administered when infection ant fever were present. Antibiotics were never used. prophylactically.

Early mobilization of the patients was considered essential and they were sat out of bed from the 2nd day after tracheostomy. They were weaned off the respirator as early as was feasible by allowing increasing periods of spontaneous respiration. Whert adequate spontaneous respiration was possible, the cuffed tracheostomy tube was replaced by a silver cannula. The inspired atmosphere was humidified and in some instances enriched with oxygen. The्D cannula was stoppered for increasing periods an of when there was sufficient evidence that secretions could be expectorated without the aid of endo tracheal aspiration, the cannula was removed. 


\section{Results}

One hundred and thirty-six episodes of respiratory failure occurred in 111 patients; the number of

TABLE 8

Number of tracheostomies per year

\begin{tabular}{rr}
\hline Year & No. \\
\hline 1955 & 1 \\
1956 & 1 \\
1957 & 2 \\
1958 & 5 \\
1959 & 10 \\
1960 & 18 \\
1961 & 14 \\
1962 & 23 \\
1963 & 18 \\
1964 & 23 \\
1965 & 21 \\
Total & 136 \\
\hline
\end{tabular}

patients treated has increased and since 1960 about twenty tracheostomies are carried out yearly (Table 8). Twenty-one patients needed repeat tracheostomies (Table 9). Seventeen patients died in the acute episode and three became respirator-dependent.

TABLE 9

Number of tracheostomies and re-tracheostomies

Male Female Total

No. of patients with one tracheostomy

$73+1700$

No. of patients with two tracheostomies

No. of patients with three tracheostomies

No. of patients with four tracheostomies

Total

$\begin{array}{rrr}73 & 17 & 90 \\ 17 & 1 & 18 \\ 2 & 0 & 2 \\ 1 & 0 & 1 \\ 93 & 18 & 111\end{array}$

Total number of tracheostomies 136.

TABLE 10

Survey of patients who died during respirator treatment

\begin{tabular}{|c|c|c|c|c|c|}
\hline Year & Group & $\begin{array}{l}\text { Age } \\
\text { (yr) }\end{array}$ & Sex & $\begin{array}{l}\text { Duration of } \\
\text { respirator } \\
\text { treatment } \\
\text { (days) }\end{array}$ & Cause of death \\
\hline 1955 & B & 63 & $\mathbf{M}$ & 2 & $\begin{array}{l}\text { Sudden and unexpected death. Autopsy showed acute } \\
\text { and subacute pancreatitis, cysts in kidneys and } \\
\text { liver and a small lung infarction. }\end{array}$ \\
\hline 1956 & $\mathbf{B}$ & 66 & $\mathbf{M}$ & 52 & Pneumonia. \\
\hline 1958 & $\mathbf{C}$ & 62 & $\mathbf{M}$ & 19 & $\begin{array}{l}\text { Numerous lung abscesses with Staph. aureus and } P \text {. } \\
\text { aeruginosa. }\end{array}$ \\
\hline 1959 & B & 67 & $\mathbf{M}$ & 70 & $\begin{array}{l}\text { Slow deterioration. Increasing oedema and falling } \\
\text { blood pressure. Two weeks before death a tracheo- } \\
\text { oesophageal fistula. No autopsy. }\end{array}$ \\
\hline 1959 & $\mathbf{C}$ & 47 & $\mathbf{M}$ & 15 & $\begin{array}{l}\text { Septicemia with } E \text {. coli and Klebsiella. Severe asthma- } \\
\text { bronchitis; pyonephrosis with calculi. }\end{array}$ \\
\hline 1960 & B & 70 & $\mathbf{M}$ & 12 & Pneumonia and cardiac decompensation. \\
\hline 1961 & C & 65 & $\mathbf{M}$ & 31 & Pneumonia with atrial fibrillation and hypotension. \\
\hline 1962 & $\mathbf{B}$ & 57 & $\mathbf{M}$ & 13 & Pneumonia with $P$. aeruginosa and Staph. aureus. \\
\hline 1963 & $\mathbf{A}$ & 56 & $\mathbf{M}$ & 21 & $\begin{array}{l}P \text {. aeruginosa pneumonia with empyema, shock, } \\
\text { anuria and emboli to the basilar artery. }\end{array}$ \\
\hline 1963 & B & 65 & $\mathbf{M}$ & 153 & $\begin{array}{l}\text { Slow deterioration. Autopsy gives no definite ex- } \\
\text { planation. }\end{array}$ \\
\hline 1964 & $\mathbf{A}$ & 44 & $\mathbf{F}$ & 10 & $\begin{array}{l}\text { Tracheostomized the day before admission at another } \\
\text { hospital, where she developed brain stem attacks. } \\
\text { Autopsy showed severe hypoxic brain lesions. }\end{array}$ \\
\hline 1964 & B & 74 & $\mathbf{M}$ & 5 & $\begin{array}{l}\text { Sudden and unexpected death after tracheal suction. } \\
\text { No definite explanation of death at autopsy. }\end{array}$ \\
\hline 1964 & B & 55 & $\mathbf{M}$ & $1 / 3$ & Hypotension after second tracheostomy. \\
\hline 1965 & $\mathbf{B}$ & 77 & $\mathbf{M}$ & 24 & $\begin{array}{l}\text { High fever at tracheostomy. After tracheostomy } \\
\text { prolonged arterial hypotension and various cere- } \\
\text { bral symptoms. }\end{array}$ \\
\hline 1965 & B & 72 & $\mathbf{M}$ & 23 & Large lung embolus. \\
\hline 1965 & B & 72 & $\mathbf{M}$ & 9 & $P$. aeruginosa pneumonia and septicemia. \\
\hline 1965 & $\mathbf{C}$ & 62 & $\mathbf{M}$ & $1 / 8$ & $\begin{array}{l}\text { Atrial fibrillation and tachycardia before tracheo- } \\
\text { stomy. After tracheostomy extreme hypotension. } \\
\text { Autopsy showed pneumonia. }\end{array}$ \\
\hline
\end{tabular}


In the other 116 episodes the patients were weaned off the respirator. As tracheostomy and artificial ventilation were employed in life-threatening situations, the immediate results of the techniques must be considered satisfactory and their adequacy is reflected in the normal results of arterial blood gas analysis during treatment (Table 3).

The causes of death during treatment are shown in Table 10. In two instances sudden unexpected death occurred for which no definite cause was found at autopsy, three patients became hypotensive and died shortly after tracheostomy and the most common cause was lung infection usually with Staphylococcus aureus or Pseudomonas aeruginosa. Most patients were weaned off the respirator rapidly (Table 11)

TABLE 11

Duration of respirator treatment

\begin{tabular}{lrcc}
\hline & Group A & Group B & Group C \\
\hline$<1$ week & $26(0)$ & $13(3)$ & $5(1)$ \\
$1-4$ weeks & $24(2)$ & $29(5)$ & $7(2)$ \\
$>4$ weeks & $6(0)$ & $17(3)$ & $9(1)$ \\
Total & $56(2)$ & $59(11)$ & $21(4)$ \\
\hline
\end{tabular}

No. of deaths during respirator treatment is given in parentheses.

but thirty-two patients required assisted ventilation for at least part of the day for more than 4 weeks. Four of these died and three are respirator-dependent cripples but the other twenty-five were eventually weaned off their ventilators.

\section{Complications during treatment}

A list of complications is presented in Table 12.

TABLE 12

Complications during respirator treatment

\begin{tabular}{lrrr}
\hline & \multicolumn{2}{c}{ Group } & \multicolumn{2}{c}{ Group } & Group \\
& A & B & C \\
\hline Total No. & 56 & 59 & 21 \\
Fall of blood pressure to less than & & & \\
$\quad$ 90 mmHg systolic & 7 & 23 & 6 \\
Anoxic kidney damage & 1 & 1 & 1 \\
Twitchings or convulsions & 11 & 8 & 7 \\
Bleeding from tracheostomy & 3 & 1 & 0 \\
Subcutaneous emphysema & 3 & 2 & 0 \\
Gastric retention or abdominal & & & \\
$\quad$ distension & 5 & 12 & 1 \\
Haematemesis/melaena & 2 & 3 & 2 \\
Pneumonia & 6 & 10 & 4 \\
Atelectasis & 2 & 0 & 0 \\
Lung infarction & 1 & 3 & 0 \\
Thrombophlebitis & 3 & 1 & 0 \\
Stenosis of trachea & 2 & 1 & 0 \\
Dilatation of trachea & 0 & 1 & 0 \\
Tracheo-oesophageal fistula & 0 & 1 & 0 \\
\hline
\end{tabular}

Systemic hypotension immediately after tracheos $\frac{\overline{\mathbb{D}}}{2}$ tomy and paralytic ileus particularly in patients witkpoor respiratory reserve were the commonest com $\Rightarrow$ : plications. Twitching occurred but convulsions were? rare if overventilation was avoided initially.

\section{Results of long-term follow-up}

Patients were returned to medical wards for re $\stackrel{\Phi}{\varrho}$ habilitation after the tracheostomy was closed About half the patients were eventually discharge 5 with the same respiratory reserve as before the acuteexacerbation but in the rest there was markedw diminution of the reserve. Seventeen patients deteriorated during their stay in the medical wardso after closure of the tracheostomy and eventually. died in cardio-respiratory failure for which IPPV was not considered indicated.

Table 2 shows that $50 \%$ of group A patients sur ${ }^{\infty}$ vived after 2-4 years whereas $50 \%$ of group BN patients died within 9 months and only $50 \%$ of group $\mathrm{C}$ survived the admission.

\section{Discussion}

Proper artificial ventilation is very effective in $\vec{\circ}$ resuscitating a patient with chronic lung disease $v$ from the life-threatening condition of severe respira-응 tory insufficiency.

The treatment with tracheostomy and IPP ventilation as described in this paper has been choseno as a standard treatment, when conservative regimen $\mathbb{Q}_{\square}^{\mathbb{Q}}$ is inadequate. In the practical organization of therapy there are definite advantages in adhering to 3 one fairly simple method, familiar to all members of the staff. Further conditions for tracheal suctiono and effective ventilation are optimal.

The procedure of tracheostomy entails in itself . a very small risk, but undoubtedly the unavoidableo bacterial colonization of the stoma represents $a$. serious risk of lung infection, particularly withô endemic hospital flora of $\boldsymbol{P}$. aeruginosa and Staph.₹ aureus (Gotsman \& Whitby, 1964). The larger the ward, the greater the risk of cross-infection.

The other significant complication-hypotension in the tracheostomy period-was usually mastered, N and should be avoidable in most cases by close supervision and application of the measures men- $N$ tioned. Both of these complications, as well as the fatalities during the tracheostomy period, were mainly seen in patients with a small respiratoryo reserve.

Might a less drastic therapy bring about equally: satisfactory results? In recent years the use of analeptics (Sadoul, 1965) and acetazolamide (Gay $\& \underset{\mathbb{\Phi}}{\stackrel{\circ}{\circ}}$ Cross, 1965) has had several advocates as a valuable improvement of the conservative therapy. Our own $\stackrel{\mathbb{Q}}{\Omega}$ experience does not allow us to comment on the use of these drugs. 
Tank respirators are still used by some authors (Grendahl \& Refsum, 1965) who stress the advantages of avoiding tracheostomy. However, in patients who are comatose and present problems of secretions in the airways, this treatment is hardly suitable. Furthermore the ventilatory capacity of most commercially available tanks is limited, and even with free airways a sufficient ventilation of patients with low compliance may prove impossible. The mobilization of the patient-an essential part of the treatment-is difficult as is nursing and last, but not least, treatment with tank respirator is more uncomfortable than tracheostomy and IPP ventilation.

IPP ventilation on a mask has given excellent results, especially in the hands of French teams (Sadoul et al., 1965). The series of patients treated seem to differ somewhat from those in the present series in comprising few comatose patients. We are not convinced that mask-ventilation would have been effective in our patients, but we intend to undertake a trial of the method, and we hope that our scepticism will be unjustified.

Recently the use of oro-tracheal or naso-tracheal intubation has been recommended in the management of respiratory failure, instead of tracheostomy. The newer types of soft plastic tubes seem to be well tolerated, even for longer periods, and the results of this treatment in larger series of patients will be met with interest.

Finally, tracheostomy or fenestration without intubation or cannulation, performed by a special technique (Rockey et al., 1961), has been advocated. The avoidance of foreign bodies eliminates the inherent risks of dilatation and stenosis of trachea and supposedly reduces the risk of infection. On the other hand, at least in our type of patients, it is to be feared that prolonged periods of hypoventilation with weak cough reflexes would present equally severe risks.

From the description of our patients it will be seen that tracheostomy and IPPV was used in many patients with a small respiratory reserve. In fact, most patients admitted to the department with lifethreatening respiratory failure were treated by this means. It is remarkable that it was possible to a large extent to bring these severely incapacitated patients back on spontaneous respiration. It also appears from the report that the condition of a number of these patients later again deteriorated, and in some cases respirator treatment was not re-instituted. The decision to be taken in those cases is dependent on whether or not the condition of the patient can be regarded as reversible or not. In the first case every effort has to be made to tide the patient over a lifethreatening situation. In the latter case such effort may be an unjustified intervention that prolongs the intolerable ultimate phase of an incurable disease.

Between these two extremes a category of patients who might benefit from permanent or intermittent respirator assistance, and who might be able to lead a tolerable life in spite of their dependence on assisted ventilation, is emerging. Such treatment might be imagined along the lines followed in the care of patients with respiratory paralysis after polio (Engberg, 1961). The social and medical aspects are complicated, and the care of such patients will add to the responsibilities of medical personnel engaged in the treatment of patients with chronic lung disease.

\section{Summary}

Data are given concerning 136 consecutive episodes of severe respiratory insufficiency in 111 patients with chronic diffuse lung disease, treated with tracheostomy and artificial ventilation with a Lundia respirator. The importance of tracheal intubation prior to tracheostomy, large cuffed tubes, low initial ventilatory volumes with oxygen-enriched air and early mobilization is stressed. The results of treatment are given, and it is shown that the outcome depends on the respiratory reserve before exacerbation and not on the age or clinical state of the patient at tracheostomy, nor on laboratory data such as blood gas analysis, ECG, etc. Two patients among fifty-six with some working ability before tracheostomy died during respirator treatment, while fifteen out of eighty more incapacitated patients died. The causes of death and the non-lethal complications during treatment are surveyed. Other possibilities of active treatment are reviewed and discussed briefly.

A follow-up study showed $50 \%$ survival after 2-4 years in patients with some working ability before the exacerbation. The corresponding figure was 9 months in the group unable to work, but able to manage personal requirements. In the third and most disabled group of patients one-half died in hospital.

\section{References}

Bates, D.V., Klassen, G.A., Broadhurst, C.A., Peretz, D.I., Anthonisen, N.R. \& SMITH, H.J. (1965) Management of respiratory failure. Ann. N.Y. Acad. Sci. 121, 781.

Bjørneboe, M., IbSen, B., Astrup, P., Everberg, G., Harvald, B., SøTtrup, T., Hess-Thaysen, E. \& ThorsHAUGE, C. (1955) Active ventilation in treatment of respiratory acidosis in chronic diseases of the lungs. Lancet, ii, 901 .

Boutourline-Young, H.J. \& Whittenberger, J.L. (1951) The use of artificial respiration in pulmonary emphysema accompanied by high carbon dioxide levels. J. clin. Invest. 30, 838 .

Bradley, R.D., Spencer, G.T. \& Semple, S.J.G. (1964) Tracheostomy and artificial ventilation in the treatment of acute exacerbations of chronic lung disease. A study in 29 patients. Lancet, i, 854.

Bydlowski, R., Hatzfeld, C., Atlan, G., Hinglais, J.-C. \& BRILLE, D. (1965) Discussion des indications des divers modes de ventilation assistée au cours des defaillances aigues chez les insuffisants respiratoires chronique. Bull. physio-pathol. Resp. 1, 424. 
Castaing, R., Chevais, R., Gillardaeu, G., FavarelGarriQues, J.-C., Courty, G. \& Ferrus, L. (1965) Bilan therapeutique de 168 cas d'insuffisance respiratoire aigue survenus chez des defaillants respiratoires chroniques. Bull. physio-pathol. Resp. 1, 463.

ENGBERG, E. (1961) Family flats with a nursing annexe. A Danish experiment for the disabled. Lancet, i, 1106.

GAY, R. \& Gross, A. (1965) Les modificateurs de l'équilibre acido-basique dans le traitement de l'hypercapnie. Bull. physio-pathol. Resp. 1, 358.

Gotsman, M.S. \& Whitby, J.L. (1964) Respiratory infection following tracheostomy. Thorax, 19, 89.

Grendahl, H. \& Refsum, H.E. (1965) Artificial ventilation with tank respirators in the routine treatment of severe pulmonary failure due to chronic pulmonary disease. Acta med. scand. 177, 539.

Herzog, H. \& Engelhart, G. (1964) Ventilation artificielle (IPPB) dans l'insuffisance respiratoire du syndrome obstructif. Rev. Tuberc. (Paris), 28, 1289.

LASSEN, H.C.A. (1956) Management of life-threatening Poliomyelitis. Livingstone, Edinburgh.

LasSen, H.C.A. (1962) Problèmes de Réanimation, 2 Serie (Ed. by A. Larcan), p. 511. Doin, Nancy.

Lissac, J. \& Pocidalo, J.-J. (1963) La tracheotomie au cours de l'emphyséme pulmonaire chronique. Étude de 80 cas personnels. Rev. Tuberc. (Paris), 27, 808. Mollaret, P., Bastin, R., RaPin, M., Pocidalo, J.-J., $\underset{\mathbb{1}}{\gtrless}$
Goulon, M., Lissac, J. \& Liot, F. (1958) La respiration artificielle dans les insuffisances respiratoires aiguës, $\stackrel{-}{\rightarrow}$ au cours des bronchopneumopathies avec cœur pulmonaire chronique. Presse méd. 66, 1271.

MunCK, O., KRISTENSEN, H.S. \& LASSEN, H.C.A. (1961) Mechanical ventilation for acute respiratory failure in $\overline{\bar{\sigma}}$ diffuse chronic lung disease. Lancet, i, 66.

Rockey, E.E., Blaszik, C.F., Thompson, S.A. \& Virabutr, S. (1961) Four and one half years' experience in the treat- $\varrho$ ment of emphysema and other respiratory insufficiencies by tracheal fenestration. Dis. Chest, 39, 117.

SADOUL, P. (1965) Use of sedatives, relaxants and respiratory $\overrightarrow{0}$ stimulants in respiratory failure. Ann. N.Y. Acad. Sci. $\overrightarrow{\vec{C}}$ 121, 836.

SAdoul, P., Aug., M.-C. \& GAY, R. (1965) Traitement par ventilation instrumentale de 100 cas d'insuffisance res? piratoire aigue sévère $\left(\mathrm{pA} \mathrm{CO} \mathrm{CO}_{2}>70\right)$ chez des pulmonaires 3 . chroniques. Bull. physio-pathol. Resp. 1, 489.

Sadoul, P., Lacoste, J. \& Saunier, C. (1961) Les gestes $\vec{\omega}$ essentiels de la réanimation respiratoire chez pulmonaires $\frac{-}{6}$ chroniques. J. frac. Méd. Chir. thor. 15, 747.

SLUITER, H.J., BLOKzIJl, E. \& VAN DiJl, W. (1963) Treatmentin of severe respiratory insufficiency in primary lung disease. $\stackrel{\overrightarrow{ }}{+}$ Actes du Symposium sur le Traitement de l'Insuffisance 0 Respiratoire (Ed. by A. Vanotti). Minerva Medica, Torino.

\section{Discussion to the paper by $\mathbf{H}$. Sund Kristensen, O. Jessen and K. Rasmussen}

FINNEGAN. I would like to illustrate the respirator treatment of acute or chronic lung disease at Whiston Hospital in the period from May 1962 to January 1966.

Twenty-two men and three women developed acute cardiorespiratory illnesses and became moribund despite

TABLE A1

Respirator treatment of acute-onchronic lung disease (May 1962 to January 1966)

\begin{tabular}{cc}
\hline Age (years) & No. of patients \\
\hline $40-50$ & 6 \\
$50-60$ & 11 \\
$60-70$ & 8 \\
Total & $25(22$ men +3 women $)$ \\
\hline
\end{tabular}

TABLE A2

Deaths during respirator treatment

\begin{tabular}{lcc}
\hline \multicolumn{1}{c}{ Causes } & $\begin{array}{c}\text { No. of } \\
\text { patients }\end{array}$ & $\begin{array}{c}\text { Days of } \\
\text { treatment }\end{array}$ \\
\hline Failure of resuscitation & 2 & 1 \\
Massive pulmonary infarcts & 1 & 3 \\
Undiagnosed carcinoma of bronchus & 1 & 6 \\
Perforated duodenal ulcer & 1 & 24 \\
Renal failure & 1 & 11 \\
Cross-infection & 2 & 10 and 11 \\
Bronchopneumonia & 1 & 13 \\
Total & 9 & \\
\hline
\end{tabular}

antibiotics, controlled oxygen and chest physiotherapy. All the patients had acute-on-chronic cor pulmonale due to chronic bronchitis, bronchiectasis or pulmonary thrombo-embolism (Table A1). The treatment of the acute illness consisted of mechanical ventilation through a tracheostomy, antibiotics and metabolic care.

The mean duration of ventilation was 10.6 days and. the range was $12 \mathrm{hr}$ to 35 days. Nine patients died during the period of respirator treatment; the causes of death are listed in Table A2.

Four patients died within 1 year and three patients within 2 years of treatment. Nine of the original group are still alive, six with moderate disability and three with severe disability (Table A3).

\section{TABLE A3}

Follow-up of nine patients surviving for 6 months to 3 years

\begin{tabular}{lcc}
\hline Disability & $\begin{array}{r}\text { Grade of } \\
\text { dyspnoea }\end{array}$ & $\begin{array}{c}\text { No. of } \\
\text { patients }\end{array}$ \\
\hline Moderate & $1-2$ & 6 \\
Severe & 3 & 3 \\
\hline
\end{tabular}

The criteria for selection, the management and the complications are similar to those reported by $\mathrm{Dr} \Omega$ Kristensen.

ROBERTSON. I note that Dr Kristensen has had some $\mathrm{N}$ complications with tracheal stenosis after IPPV, and $\widetilde{\gamma}$ wonder whether this was because the cuff of the rubber 0 tube was blown up too tight, perhaps by the nursing staff, $\frac{C}{\mathscr{D}}$ since this has been the experience of Mr Peter Gibson of Perth, Australia.

Finally, may I ask whether anyone in the audience has any properly controlled evidence that either methylor acetyl-cysteine is effective? I have heard many speakers praise its usefulness, but I am more impressed by the $\varrho$ absence of any properly controlled trial.

SCARrow. Pulmonary angiography was employed to 